\title{
CHEMICAL, CLINICAL, AND IMMUNOLOGICAL STUDIES ON THE PRODUCTS OF HUMAN PLASMA FRACTIONATION. XXXIX. THE ANEMIA OF INFECTION. STUDIES ON THE IRON-BINDING CAPACITY OF SERUM ${ }^{1}$
}

\author{
By G. E. CARTWRIGHT AND M. M. WINTROBE
}

(From the Department of Medicine, University of Utah, School of Medicine, Salt Lake City)

(Received for publication June 14, 1948)

It has been generally recognized since Barkan's original observations in 1929 (1) that the iron in serum is non-dialyzable and non-ultrafilterable at $\mathrm{pH} 7.3$ and, therefore, is probably protein-bound (2-4). To which of the serum proteins the iron is bound was not clearly established until recently. Earlier work indicated that half-saturation with ammonium sulfate precipitated serum iron quantitatively together with the globulins (5). Vahlquist (4) with the aid of the electrophoretic technique concluded that the iron in serum is bound to both albumin and globulin, the $\alpha$ and $\beta$ globulins serving as the principal carriers.

Following their demonstration of a protein component in raw egg white capable of binding iron (6), Schade and Caroline investigated various fractions of human plasma prepared by E. J. Cohn . and his associates for a similar property (7) and discovered that, qualitatively, Fraction IV-3, 4 was active in this respect, as shown by biological and colorimetric tests. By colorimetry it was found that $1 \mathrm{mg}$. of protein took up a maximum of 0.44 $\mu \mathrm{g}$ of $\mathrm{Fe}^{++}$. Subfractionation of Fraction IV-3, 4 revealed that the iron-binding protein resides almost completely in a $\beta_{1}$ globulin (Fraction IV-7) (8). This fraction constitutes approximately 3 per cent of the total plasma protein. ${ }^{2}$ Two molecules of either $\mathrm{Fe}^{++}$or $\mathrm{Fe}^{+++}$are bound to one of protein. If the molecular weight of the $\beta_{1}$ globulin is 90,000 , the iron content of the iron-protein complex is 0.125 per cent. Studies over a wide range of $\mathrm{pH}$ have revealed that at neutral $\mathrm{pH}$ the iron is non-dialyzable whereas at $\mathrm{pH} 5$ the iron becomes dialyzable.

1 This paper is No. VIII in the series, "The Anemia of Infection," from the Department of Medicine, University of Utah, School of Medicine. It has been aided by a grant from the United States Public Health Service and by grants from the Upjohn Company and Parke, Davis and Company.

2 Cohn, E. J., Personal communication.
Skouge (9) and Waldenström (10) have pointed out that the concentration of serum iron five minutes after the intravenous injection of iron is lower than would be expected on the basis of the quantity injected. This "braking" phenomenon was more pronounced in patients with pernicious anemia in relapse than in normal persons. When the initial serum iron was high, scarcely any rise was noted after the intravenous injection of iron. Furthermore, toxic reactions were observed long before the generally tolerated dose of $10 \mathrm{mg}$. had been administered. Holmberg and Laurell (11) by means of a colorimetric method in which $\alpha-\alpha$ 'dipyridyl was used, were able to study the capacity of serum to bind iron in vitro. They found the "saturation limit" in 10 normal subjects to be $312 \mu \mathrm{g}$ per cent (range 264 to $366 \mu \mathrm{g}$ ). The saturation values corresponded well with the maximum values of approximately $291 \mu \mathrm{g}$ per cent obtained by Waldenström (10) after the intravenous injection of $10 \mathrm{mg}$. of $\mathrm{Fe}^{++}$. These authors explain the "braking effect" observed by Waldenström by assuming that the unbound iron is rapidly eliminated from the circulation. Toxic effects after the intravenous administration of iron were noted only when the saturation limit was exceeded and surplus iron left the blood stream.

Laurell (12) has recently published a comprehensive monograph on the iron-binding component in human plasma. In 100 normal subjects the mean value for the iron-binding capacity of the serum was $315 \pm 3.3 \mu \mathrm{g}$ per cent. In pregnancy, infectious hepatitis, and acute and chronic blood loss the capacity of the serum to bind iron was found to be increased. In acute and chronic infections, pernicious anemia, hemolytic anemia, cirrhosis of the liver, uremia and malignancy the capacity was found to be diminished. On the basis of these results Laurell has advanced the hypothesis that the body is capable of mobilizing iron from 
the depots and, at the same time, can increase the absorption of iron by either lowering the serum iron concentration or by increasing the iron-binding component of the serum. Conversely, by either increasing the serum iron or lowering the ironbinding protein component more iron can be transferred to the depots and the absorption of iron checked.

Studies in this laboratory dealing with the pathogenesis of the anemia of infection have revealed that in the presence of infection a disturbance in iron metabolism occurs $(13,14)$. There is a pronounced and persistent hypoferremia and when iron is injected intravenously the magnitude of the subsequent increase in plasma iron is less than in normal individuals. The rate of disappearance of iron from plasma following injection has been found to be twice that seen in normal subjects. Neither by repeated intravenous injections nor by the continuous intravenous infusion of iron has it been possible to increase the iron level beyond a certain point. A "braking" mechanism thus operates in the presence of infection which is so powerful that as more iron is given it becomes increasingly difficult to maintain the plasma iron concentration.

In view of these observations it was thought desirable to investigate the role of the iron-binding protein of the serum in the pathogenesis of the anemia of infection. The purpose of this paper is to describe in vitro and in vivo studies of the ironbinding capacity of serum in normal subjects, in patients with infection, and in animals in which infections were produced experimentally.

\section{METHODS}

Preparation of serum. From fasting subjects an amount of venous blood sufficient to provide 8 to $10 \mathrm{ml}$. of serum was drawn without hemolysis into a syringe and transferred to a centrifuge tube. The blood was allowed to clot, the latter was separated from the glass and the blood was then centrifuged at about 2500 r.p.m. for 15 minutes. The serum was then transferred to a second centrifuge tube and respun to remove all red cells. All determinations were made within three hours after the blood was collected.

Serum iron $(S I)$. For the determination of serum iron the method of Barkan and Walker (15) using the Evelyn photoelectric colorimeter was followed except that twice the quantities recommended by them were used. This required $4 \mathrm{ml}$. of serum. The results are expressed in $\mu \mathrm{g}$ per cent.

Unsaturated iron-binding capacity (UIBC). For the determination of the unsaturated capacity to unite with iron, i.e., the binding capacity in addition to that which is already fixed (SI), a modification of the method of Schade and Caroline (7) was used. This method is based on the principle that the iron-protein compound is salmon pink in color (maximum absorption at about $460 \mathrm{~m} \mu$ ) and that the color development is proportional to the amount of iron-protein formed. The serum is therefore titrated with iron until the maximum color develops. The results are expressed in terms of $\mu \mathrm{g}$ of iron bound.

Two ml. of serum and $8 \mathrm{ml}$. of 0.9 per cent saline are added to each of two colorimeter tubes. Using the Evelyn photoelectric colorimeter and the 490 filter, the blank is set at 100 per cent transmission. The per cent transmission of the other tube is then read. One-tenth $\mathrm{ml}$. of glass-distilled water is added to the blank and

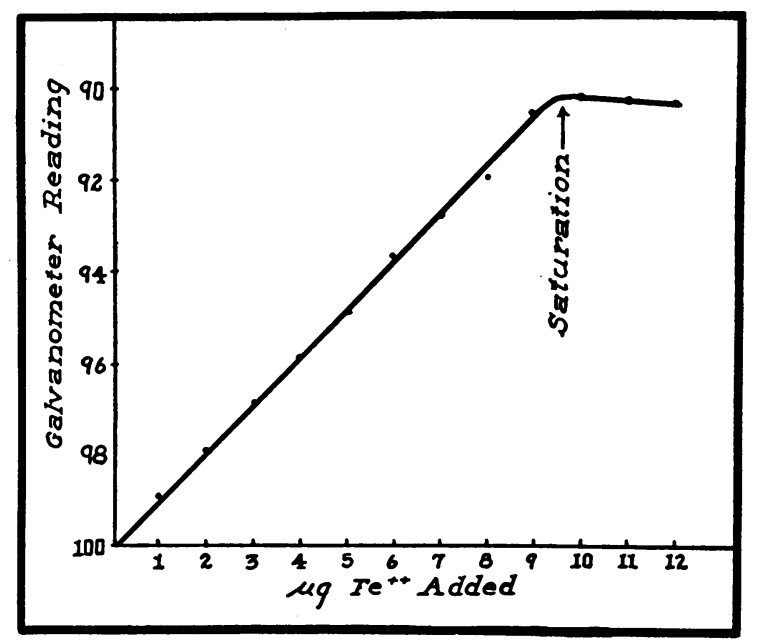

Fig. 1. Measurement in Human Serum of the Salmon Pink Color Due to the Formation of the Iron-Protein CoMplex

Evelyn photoelectric colorimeter. Filter 490.

$0.1 \mathrm{ml}$. of a standard iron solution containing $1 \mu \mathrm{g}$ of iron is carefully added to the other tube. The tubes are shaken and the per cent transmission is determined four minutes after shaking, again setting the blank at 100. This procedure is repeated until there has been no change in the per cent transmission on three successive readings. The per cent transmission is then plotted against the micrograms of iron added and the saturation pcint is estimated as illustrated in Figure 1.

The UIBC is calculated by multiplying by 50 the micrograms of iron needed to produce saturation. The values are expressed in $\mu \mathrm{g}$ per cent and represent the micrograms of iron with which $100 \mathrm{ml}$. of serum are capable of uniting.

Total iron-binding capacity (TIBC). This is calculated by adding the unsaturated iron-binding capacity to the serum iron and is expressed in $\mu \mathrm{g}$ per cent.

Per cent saturation. This is calculated by dividing the serum iron by the total iron-binding capacity. 
All glassware must be carefully cleaned with concentrated $\mathrm{HCl}$, washed three times with glass-redistilled water and air dryed under cover.

A standard iron solution is prepared by dissolving 0.1 gm. of standard iron wire in $50 \mathrm{ml}$. of $1: 3$ nitric acid. The solution is boiled to expel oxides of nitrogen and is then diluted to 1 liter with glass-distilled water. A dilute working standard containing $10 \mu \mathrm{g}$ of iron per $1 \mathrm{ml}$. is prepared from this. If properly stored this solution will not change in concentration for several months.

Comment. This method has been found to work equally well when either ferric ammonium sulfate or iron wire is used for the standard solution. The absorption spectrum of the pink iron-protein compound has a rather broad base with a maximum absorption at about $460 \mathrm{~m} \mu$. For this reason any filter between 420 and $520 \mathrm{~m} \mu$ is suitable but less interference from hemoglobin and bile pigment compounds is encountered in the region of 490 $\mathrm{m} \mu$. One to three minutes are required for the development of maximum color after the addition of iron. Fresh, non-lipemic, non-icteric serum must be used. If sufficient scrum is not available for a blank this may be dispensed with although the accuracy of the method is thereby slightly reduced. The concentration of the chromogen is low and great care must be taken in making the readings.
Since increments of $1 \mu \mathrm{g}$ iron are added to $2 \mathrm{ml}$. of scrum and the results are multiplied by 50 in order that they may be expressed in $\mu \mathrm{g}$ per cent the method can be no more accurate than $50 \mu \mathrm{g}$ per cent. However, triplicate determinations on the same serum have repeatedly given the same result.

\section{EXPERIMENTAL}

To determine whether the in vitro measurement of the TIBC of the serum is a true measure of the ability of the serum to combine with iron in vivo, an amount of iron calculated to exceed the determined TIBC was injected intravenously into each of eight individuals. The iron was administered in the form of a 0.5 per cent solution of iron ascorbate in amounts equivalent to $0.137 \mathrm{mg}$. Fe $\mathrm{Fe}^{++}$ per kilogram of body weight. An initial sample of blood was withdrawn, the iron solution injected in 30 to 60 seconds, and five minutes later a second sample was taken from the other arm. The results are presented in Figure 2. In each instance

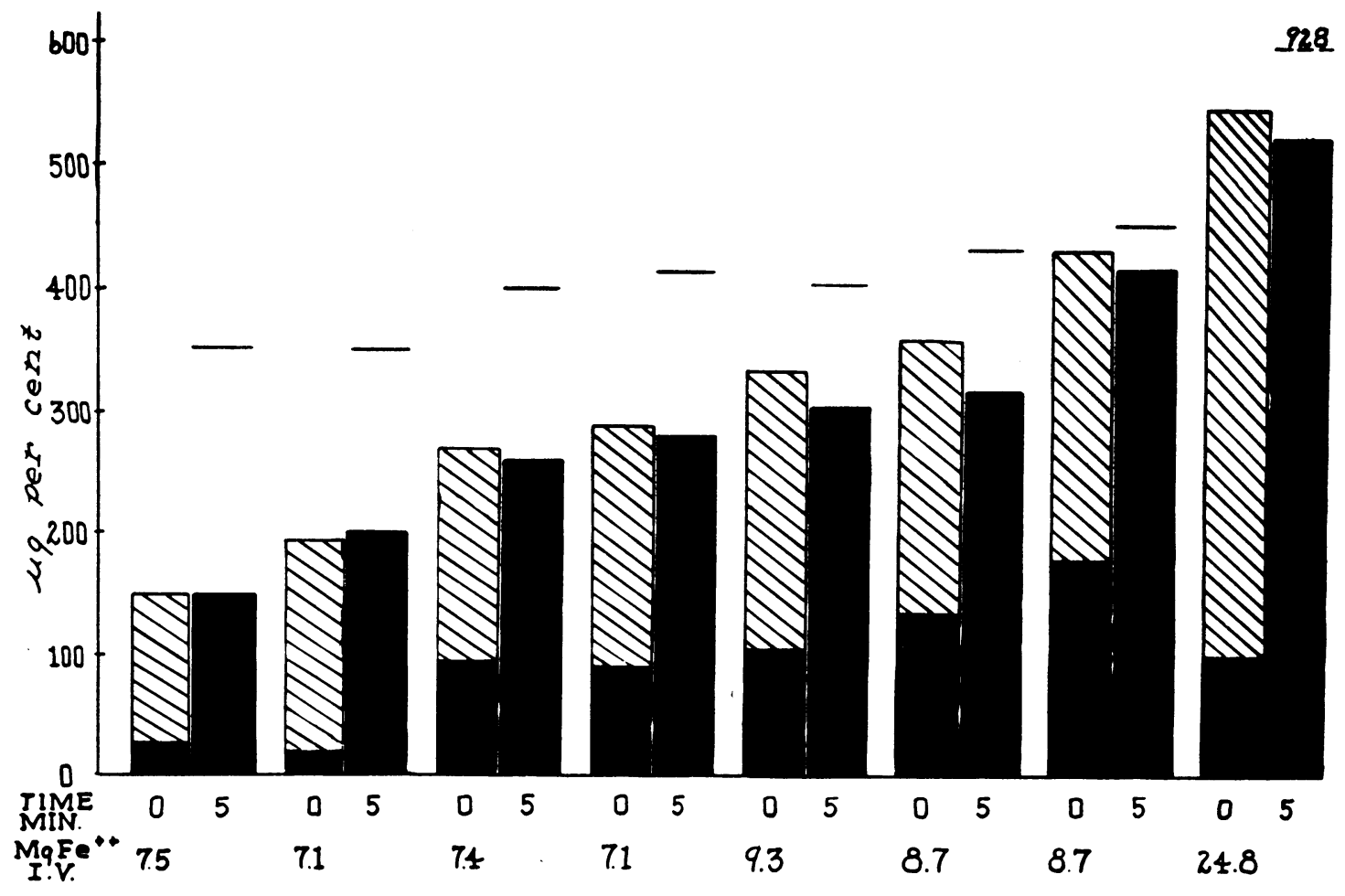

Fig. 2. Comparison of the Serum Iron Level, the Unsaturated Protein and the Total IronBinding Capacity Before and After the Intravenous Injection of Iron

The horizontal lines represent the expected serum iron values as calculated from the amount of iron administered and the estimated plasma volume. Solid areas represent the serum iron; hatched areas represent the unsaturated capacity to bind iron. The total height of each column represents the total iron-binding capacity. The amount of iron $\left(\mathrm{Fe}^{++}\right)$injected is indicated below the various columns. 


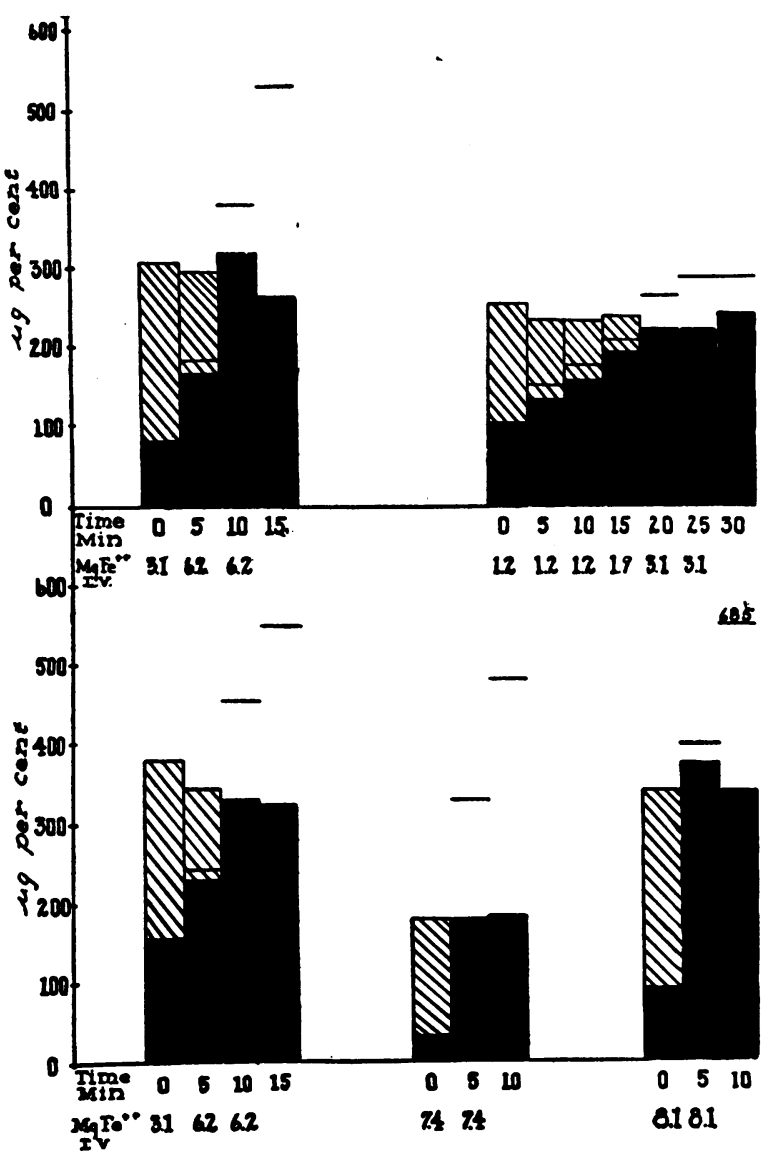

Fig. 3. Results of the Repeated Intravenous Injection of Iron at Five-Minute Intervals in Each or Five Patients

The horizontal lines represent the expected serum iron values on the basis of the amount of iron administered and the calculated plasma volume. Solid areas represent the serum iron. Hatched areas represent the unsaturated iron-binding capacity. The total height of each column represents the total iron-binding capacity. The amount of iron $\left(\mathrm{Fe}^{++}\right)$injected is indicated below the various columns.

the serum was completely saturated with iron $(\mathrm{UIBC}=0)$ and the measured amount of serum iron corresponded, within the limits of the experimental error, to the previously determined TIBC. A reaction to the injection, manifested by headache, flushing and nausea, was noted within two minutes in each individual. By the time the second specimens were withdrawn the reactions had completely disappeared.

The results of the repeated injection of iron at five-minute intervals into each of five patients are presented in Figure 3. After complete saturation had been attained the loss of additional iron from the serum within five minutes was approximately 100 per cent. Repeated injections of iron failed to raise the serum iron level above the TIBC. However, when amounts insufficient to reach the saturation limit were given, not all of the iron was retained in the serum, only 50 to 80 per cent being accounted for when plasma volume was calculated as equivalent to $43.1 \mathrm{ml}$. per kilogram of body weight for males, and $41.5 \mathrm{ml}$. per kilogram for females. Since it is unlikely that the calculated plasma volume would be in error to the extent of 50 per cent, it is possible that in some instances iron escaped to the tissues even though the serum possessed the capacity to bind it. Toxic reactions were observed only when the TIBC was exceeded.

Determinations of the TIBC have been made in 15 normal males and 15 normal females. The results are presented in Table $I$. The mean \pm S.D. for the entire group was $359 \pm 30.8 \mu \mathrm{g}$ per cent and the range 306 to $429 \mu \mathrm{g}$ per cent. The values for the female group were somewhat higher than for the male group. In these normal subjects $35 \pm 6.4$ per cent (26 to 49 ) of the total iron-binding capacity was saturated.

Studies have been made on 13 patients with chronic infections and six patients with iron deficiency anemia. The results are presented in Figure 4. In chronic infections, in each instance, the TIBC as well as the serum iron was reduced below the lower limits of normal. The reduction in serum iron was proportionately greater than the decrease in $T I B C$, the per cent saturation being

TABLE I

Summary of the normal data

\begin{tabular}{c|c|c|c|c|c}
\hline \hline Group & $\begin{array}{c}\text { No. } \\
\text { determ. }\end{array}$ & UIBC & SI & TIBC & $\%$ Sat. \\
\cline { 2 - 4 } Males & 15 & $\begin{array}{c}220 \pm 24.7 \\
(180-250)\end{array}$ & $\begin{array}{l}127 \pm 29.2 \\
(79-196)\end{array}$ & $\begin{array}{l}347 \pm 26.1 \\
(306-396)\end{array}$ & $\begin{array}{l}36 \pm 7.78 \\
(24-49)\end{array}$ \\
Females & 15 & $\begin{array}{l}248 \pm 34.4 \\
(200-300)\end{array}$ & $\begin{array}{l}123 \pm 19.2 \\
(101-164)\end{array}$ & $\begin{array}{l}371 \pm 35.9 \\
(316-429)\end{array}$ & $\begin{array}{l}33 \pm 4.92 \\
(26-42)\end{array}$ \\
\hline Total & 30 & $\begin{array}{l}234 \pm 29.4 \\
(180-300)\end{array}$ & $\begin{array}{l}125 \pm 24.2 \\
(79-196)\end{array}$ & $\begin{array}{l}359 \pm 30.8 \\
(306-429)\end{array}$ & $\begin{array}{l}35 \pm 6.4 \\
(26-49)\end{array}$ \\
\hline
\end{tabular}

UIBC refers to unsaturated iron-binding capacity in $\mu g$ per cent.

SI refers to serum iron in $\mu \mathrm{g}$ per cent.

TIBC refers to total iron-binding capacity in $\mu \mathrm{g}$ per cent.

$\%$ Sat. (per cent saturation) $=\frac{\text { SI }}{\text { TIBC }}$.

Figures represent mean \pm standard deviation.

Figures in parenthesis represent range. 
between 7 and 26 per cent in all but two patients. In these two cases the decrease in serum iren was proportional to the decrease in TIBC and the per cent saturation remained within the limits of normal (26 to 49 per cent). In contrast, in the patients with iron deficiency anemia the TIBC was increased above $450 \mu \mathrm{g}$ per cent. Since the serum iron is very low in iron deficiency, the per cent saturation was below 10 in all.

The change in TIBC in relation to the rise in serum iron which occurs during recovery from infections was followed in six patients. The results are presented in Figures 5-9, and 12. These studies showed that in infections the total iron-binding capacity per $100 \mathrm{ml}$. serum increased, as did the serum iron, following successful treatment and anemia, when present, tended to disappear (Figures 5-7). The per cent saturation of the ironbinding protein with iron did not change greatly.
In a more chronic infection (Figure 8) the changes following streptomycin therapy were very gradual but in another case (lung abscess, Figure 9) the improvement following thoracotomy was more striking.

To determine if the intravenous administration of metal-combining globulin (Fraction IV-7) together with iron might increase the TIBC to normal and thereby prevent the rapid disappearance of iron from the serum which occurs in the presence of infection, these substances were given to two patients with chronic infections. In each patient the rate of disappearance of iron from the serum after its intravenous injection was measured two days prior to the administration of the metalcombining globulin, sample measurements being taken at 0 , five min., one, three, five, seven, 24,48 and 96 hours after the injection. The amount of globulin to be administered was then added to 500

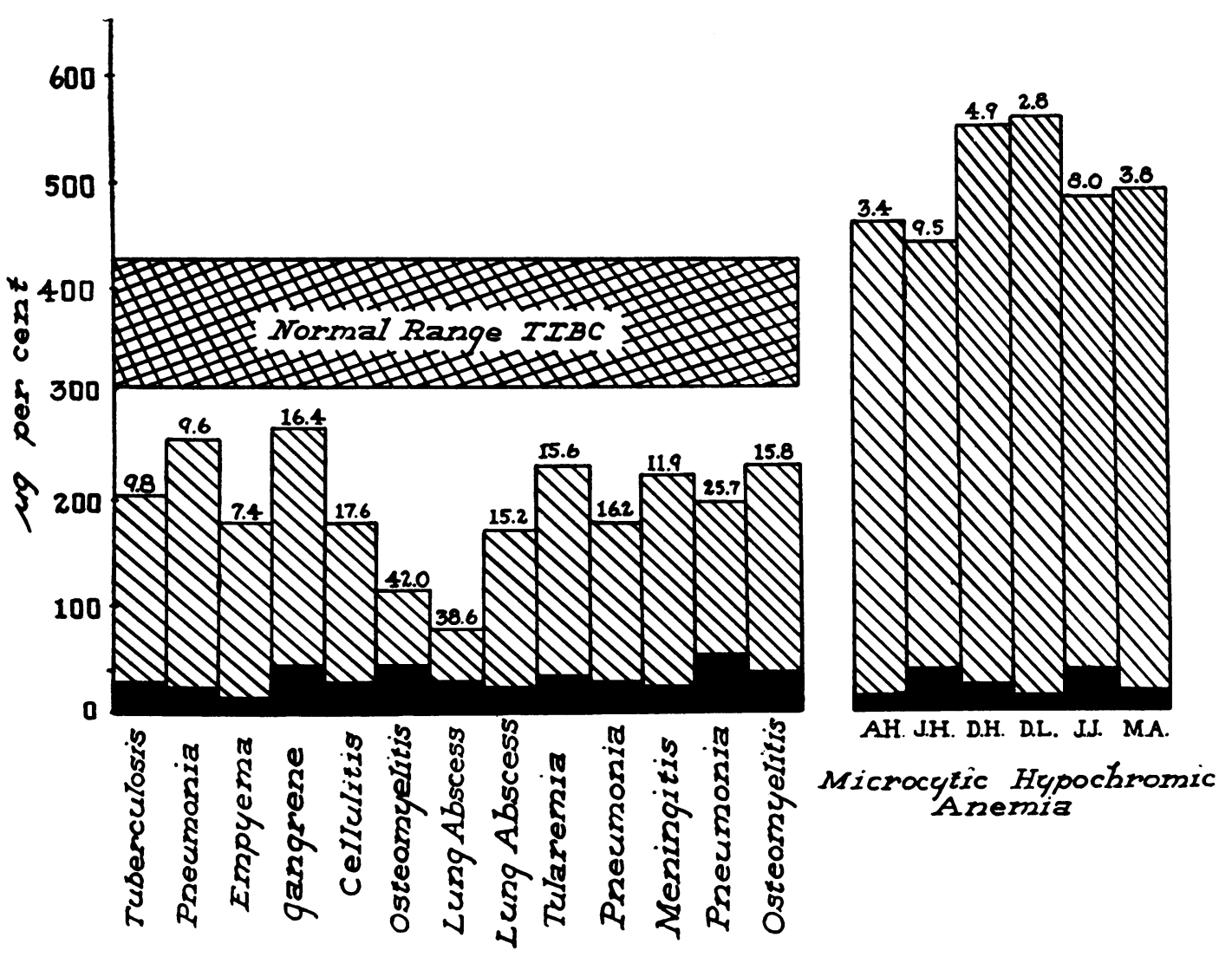

Fig. 4. The Total Iron-Binding Capacity of the Serum in 13 Cases of Anemia Associated with Infection as Compared with the Normal and Six Cases of Iron Deficiency Anemia

Solid areas represent serum iron. Hatched areas represent the unsaturated iron-binding capacity. The total height of each column represents the total iron-binding capacity of the serum. The figures above the columns represent the per cent saturation (SI/TIBC). 


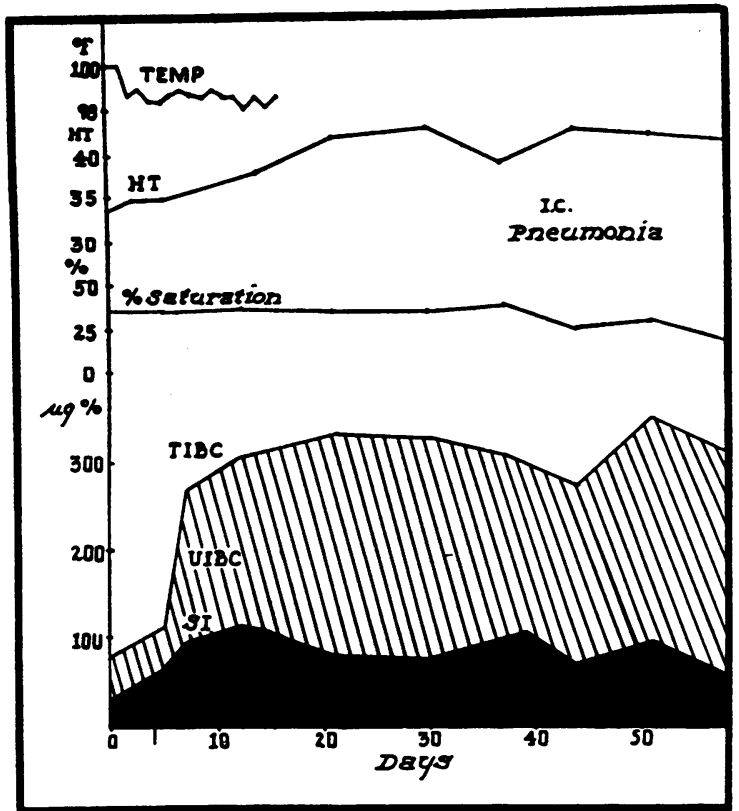

Fig. 5. Showing the Sharp Rise in the IronBinding Capacity of the Serum (TIBC) in a Patient (I. C.) Recovering from Lobar Pneumonia, the Increase in Serum Iron (SI) and the Disappearance of Anemia (Represented by the Volume of Packed Red Cells (Ht.))

UIBC refers to unsaturated iron-binding capacity. Per cent saturation is the ratio of SI to TIBC.

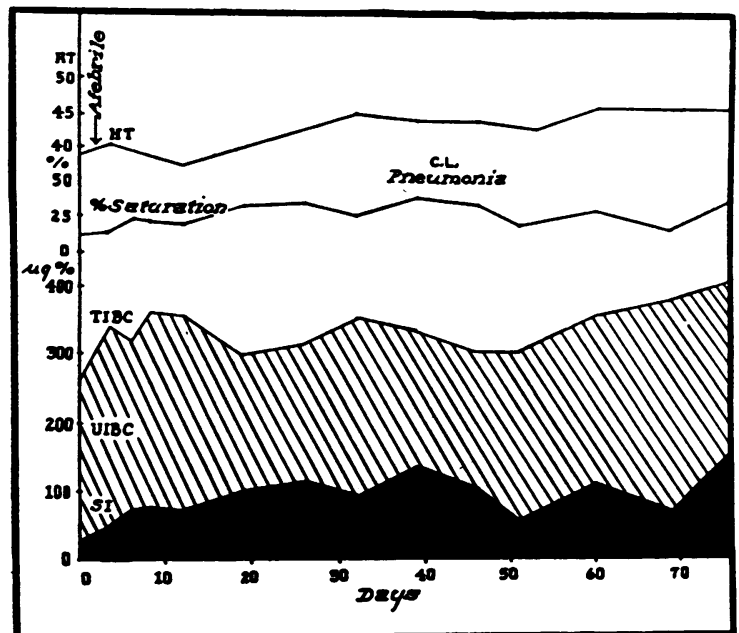

Fig. 6. Showing the Rise in the Iron-Binding Capacity of the Serum in a Patient (C.L.) Recovering from Lobar Pneumonia, the Irregular Increase in Serum Iron and the Disappearance of Anemia

For symbols see Figure 5.

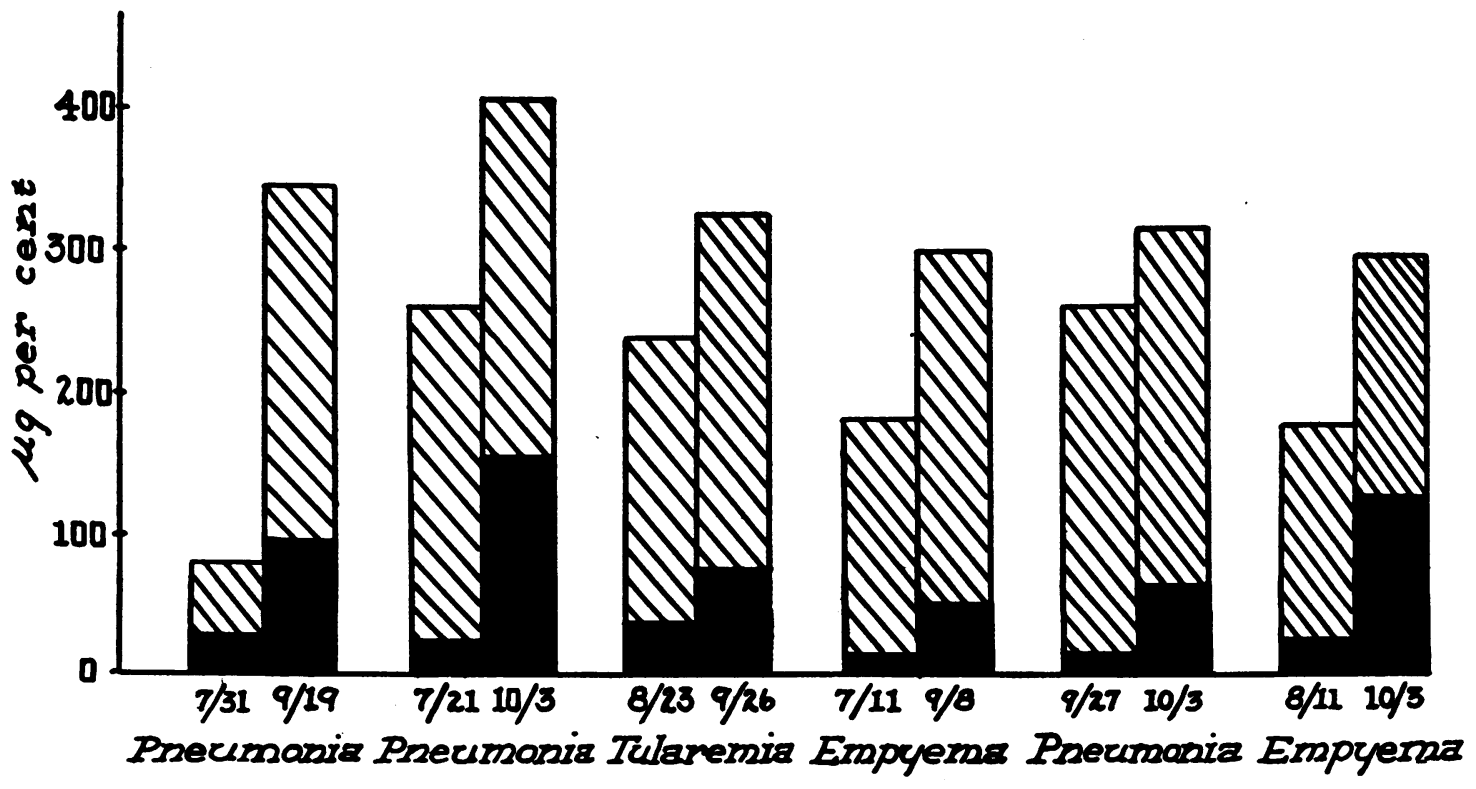

Fig. 7. Unsaturated Iron-Binding Capacity, Serum Iron and Total Iron-Binding Capacity in Six Cases during the Height of the Illness and after Recovery

For symbols see Figure 2. 


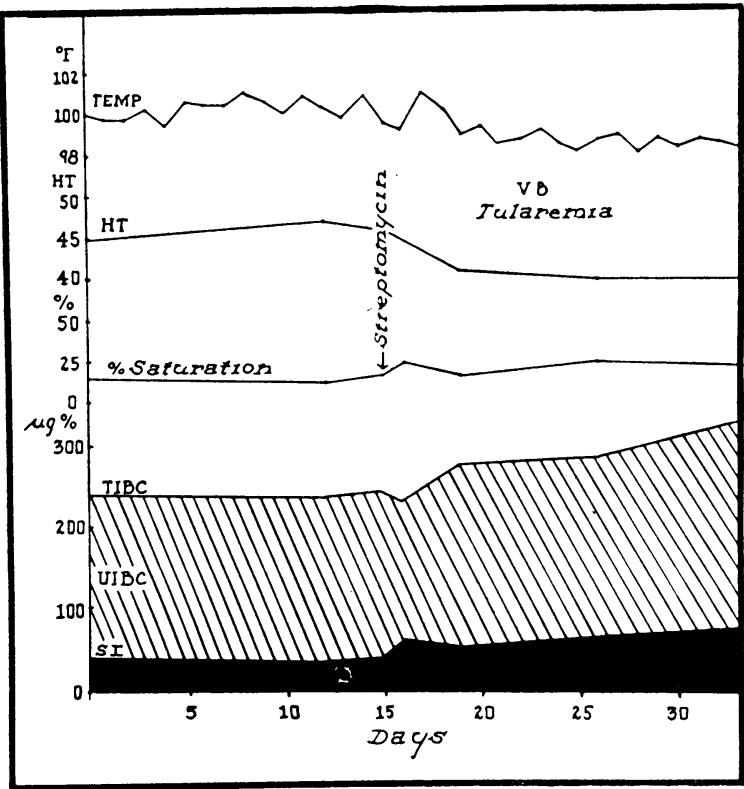

Fig. 8. Showing the Slight Rise in the IronBinding Capacity of the Serum in a Patient (V. B.) DURING Recovery from Tularemia

For symbols see Figure 5.

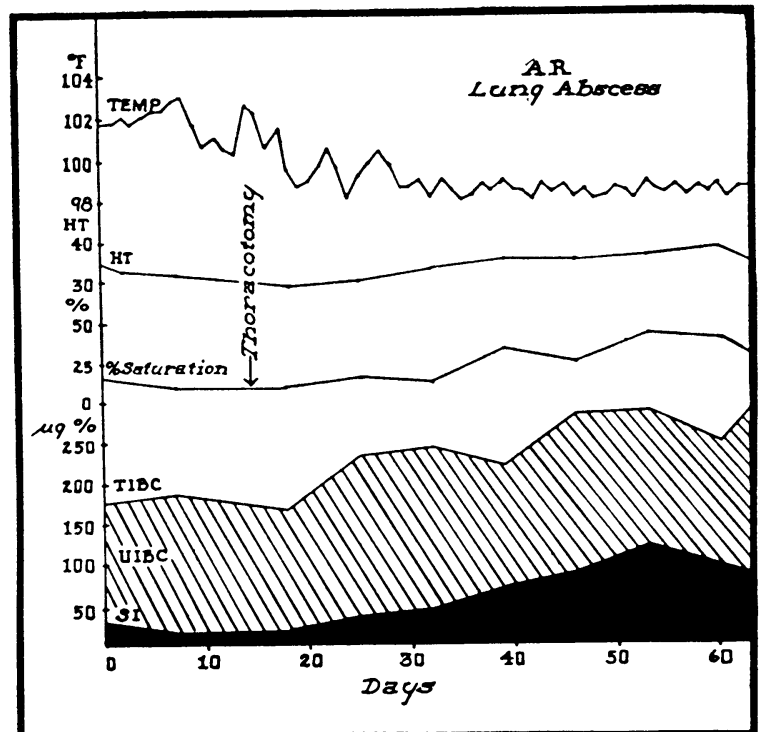

Fig. 9. Showing the Rise in the Iron-Binding Capacity of the Serum, the Rise in Serum Iron and Minimal Improvement in Anemia in a Patient (A. R.) FOLlOWING ThORACOTOMY FOR a LUNG AbSCESS

For symbols see Figure 5.

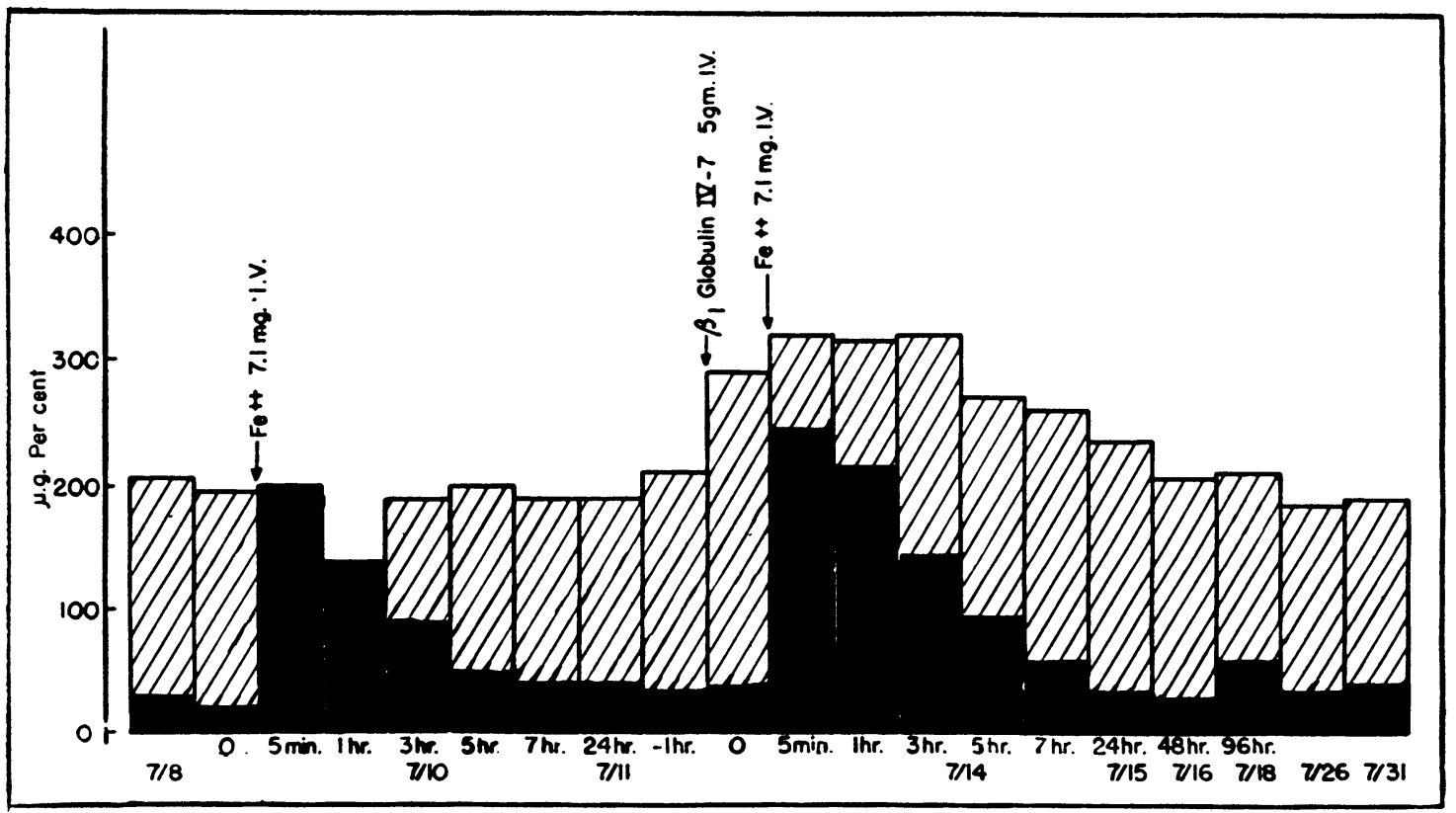

Fig. 10. The Effect of the Injection of 5 Gm. of Metal-Combining Globulin (Fraction IV-7) on the Total Iron-Binding Capacity of the Serum in a Patient (J.A.) with Tuberculosis

For symbols see Figure 2. The serum iron rose to a somewhat higher level following the injection of iron than before globulin was given and the subsequent decrease in serum iron was slower but after 24 hours the level was the same as originally. 


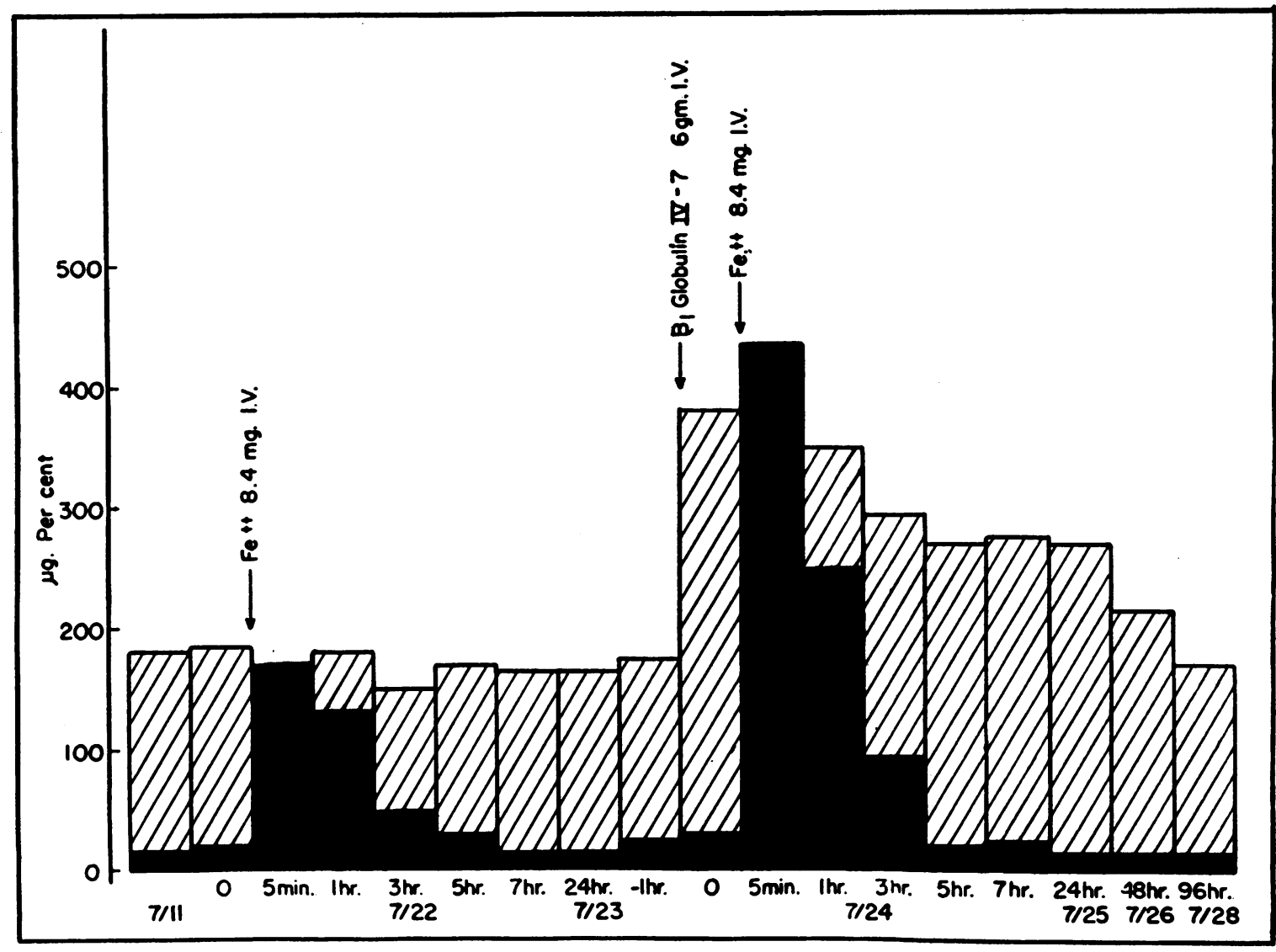

Fig. 11. The Effect of the Injection of 6 Gm. of Metal-Combining Globulin (Fraction IV-7) on the Total Iron-Binding Capacity of the Serum in a Patient (J. K.) with Chronic Empyema

Although the TIBC increased to a higher level than in patient J. A. (Figure 10) this did not succeed in maintaining an elevated serum iron level. For symbols see Figure 2.

ml. of saline and given over a one-hour period. Five minutes after this was completed a sample of blood was withdrawn for analysis and the same quantity of iron injected ( $0.137 \mathrm{mg}$. per kilogram body weight) as had been given two days previously. The results are presented in Figures 10 and 11 and illustrate several points of interest. The administration of the metal-combining globulin increased the TIBC to within normal limits in both patients. The iron-binding capacity of the protein injected was $0.72 \mu \mathrm{g} \mathrm{Fe}^{++}$per milligram of protein. Therefore, all of the material injected could be accounted for in the serum on the basis of the calculated plasma volume. There was no evidence of inactivation of the binding capacity within two to three hours. The levels of serum iron reached when metal-combining globulin was given in addition to iron were somewhat higher in one case and much greater in the second case, as compared with those obtained when iron was injected alone. The rate of disappearance of iron from the serum was not diminished, however. In both individuals the serum iron returned to its previously low level within seven hours in spite of the increased TIBC. The TIBC returned to its previously low level in 48 hours in one patient (Figure 10) and in 96 hours in the other (Figure 11). The temporary restoration of the TIBC to normal in these cases apparently did not result in a detectable mobilization of iron from the tissues to the blood.

It is of interest to note that while the intravenous injection of metal-combining globulin together with iron was not followed by a significant change in the serum iron, thoracotomy with relief of the underlying disorder was associated with a steady increase in total iron-binding capacity, a gradual 


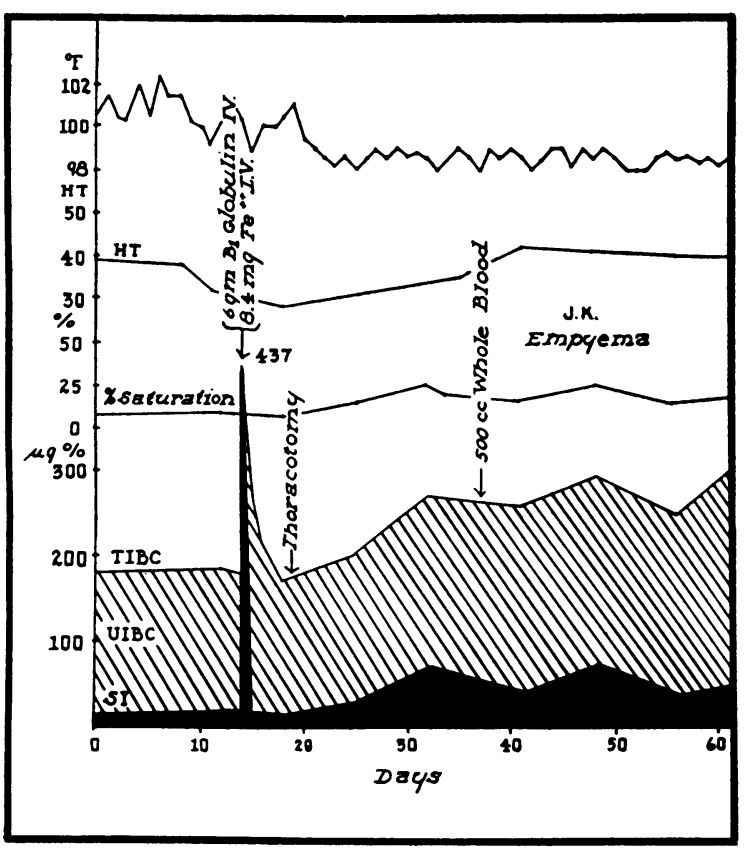

Fig. 12. To Compare the Very Transient Rise in the Total Iron-Binding Capacity and Serum Iron in a Patient (J. K.) following the Injection of 6 Gm. of Metal-Combining Globulin (Fraction IV-7) and $8.4 \mathrm{Mg}$. FE ${ }^{++}$as Iron Ascorbate with the Steady Rise Following Thoracotomy with Relief of the EMPYEMA

The serum iron also rose. The saturation of the ironbinding protein with the iron increased and the anemia disappeared. (Same patient as in Figure 11.) For symbols see Figure 5 .

rise in serum iron, increased saturation of the ironbinding protein with iron and relief of the anemia (Figure 12).

Since it has been demonstrated that patients during febrile paroxysms following the administration of typhoid vaccine rapidly develop hypoferremia (16) the TIBC was followed in such a patient during two paroxysms of fever (Figure 13). No significant change took place even though hypoferremia developed.

In an attempt to determine the rapidity with which a reduction in TIBC takes place in the presence of inflammation, an abscess was produced in a dog by the intramuscular injection of staphylococci (Figure 14). Twenty-four hours after the production of the infection the SI had fallen from $130 \mu \mathrm{g}$ per cent to $35 \mu \mathrm{g}$ per cent. There was also a reduction in the TIBC at this time but maximum reduction did not take place until the third day at which the SI had returned to normal. Two other dogs received repeated injections of turpentine (Figures 15 and 16). In each animal, 24 hours after an injection hypoferremia developed and a fall in the TIBC occurred. The decrease in serum iron was always greater than the decrease in TIBC and the per cent saturation thus decreased. In each instance the maximum decrease in TIBC took place after maximum hypoferremia had developed with the result that as the SI rose the per cent saturation increased. Following three of the six injections the serum became 100 per cent saturated during the rebound in iron content.

\section{DISCUSSION}

In 13 patients with chronic infections, in two dogs in which sterile abscesses were produced and in a single dog in which an acute infection was introduced, the total iron-binding capacity (TIBC) of the serum was reduced as compared with the normal, as was the serum iron. The reduction in the latter was proportionately greater, with the result that the per cent saturation with iron was decreased. The intravenous administration of the iron-binding protein to two patients with chronic infections increased the TIBC of the serum to nearly normal values for a period of approximately 24 hours without diminishing the rate of disappearance of iron from the serum. Furthermore, in a patient given typhoid vaccine hypoferremia developed without a significant change in the TIBC of the serum. Again, in the dogs given injections of turpentine or staphylococci hypoferremia preceded the maximum fall in TIBC; in both dogs and patients, even though the TIBC was diminished, the per cent saturation of the protein with iron was also reduced due to the greater fall in serum iron; and finally, there appeared to be no correlation between the degree of hypoferremia and anemia and the degree of reduction of the TIBC. From these observations it would appear that some factor other than a reduction in the iron-binding protein is responsible for the hypoferremia associated with infection. Since in conditions in which the demands of the body for iron are increased, namely, iron deficiency and pmegnancy, there is an increase in the TIBC of the serum, and since in those disorders in which the demand of the body for iron is decreased such as pernicious anemia in relapse (12), there is a decrease in the TIBC, 


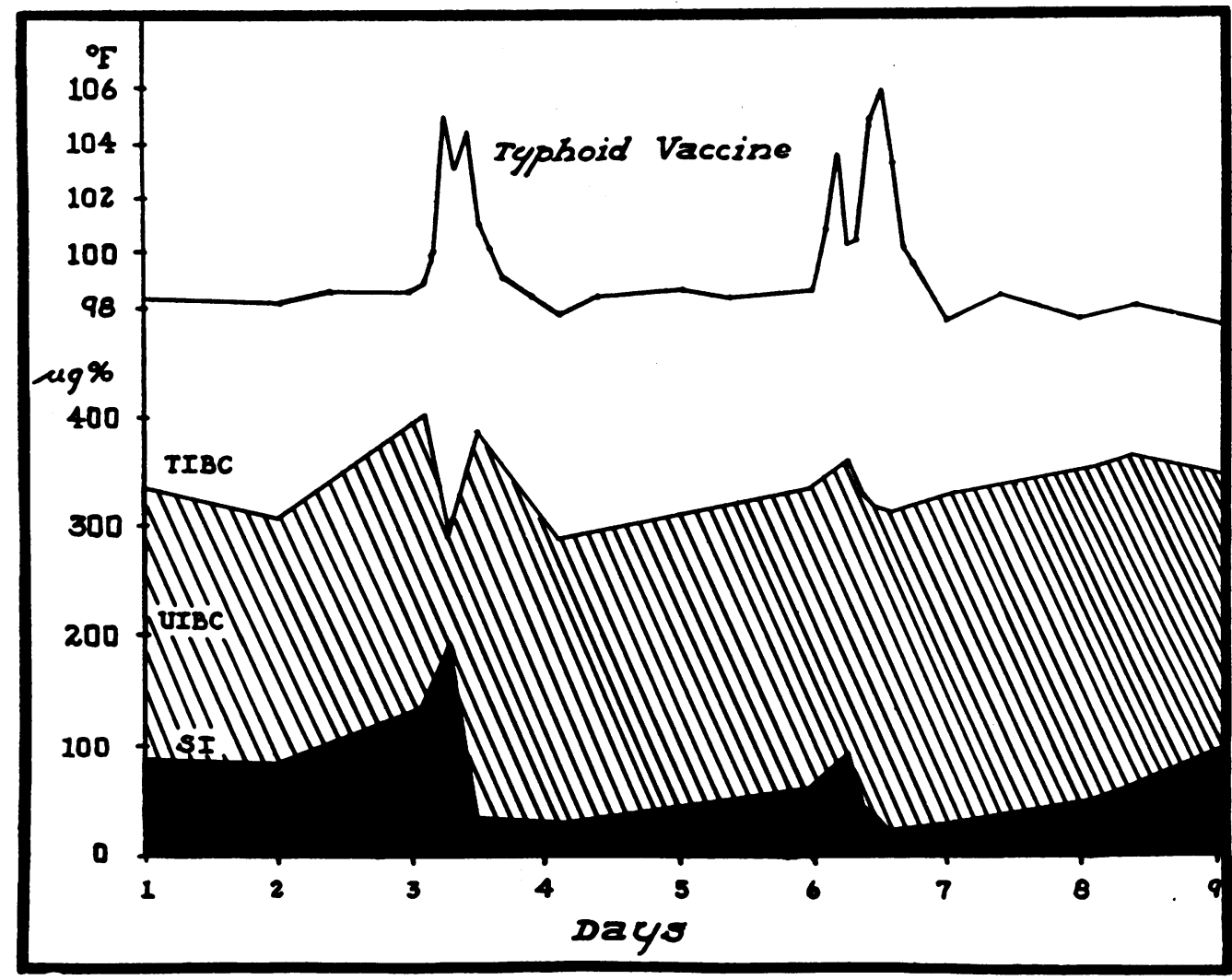

Fig. 13. The Effect of Fever Induced by the Injection of Typhoid Vaccine on the Total Iron-Binding Capacity and the Serum Iron For symbols see Figure 5.

the question might be asked: Does the reduction in TIBC in infection reflect an attempt to reduce the intake of iron? With the information now available this question cannot be answered.

In most of the patients with infections the TIBC was reduced to about 43 per cent of the normal mean and in one patient the value was reduced 78 per cent. The total serum proteins were in general within the normal range although occasionally they were in the lower limits of normal. Thus the reduction in the iron-binding protein was out of porportion to the general reduction in serum proteins.

From our observations it would appear that after the intravenous administration of iron the height of the rise is limited by the capacity of the serum to bind iron. When the TIBC of the serum is exceeded the unbound iron rapidly leaves the blood stream and toxic symptoms develop. Since the TIBC is reduced in infections an explanation is now available for our previous observation that the initial five-minute rise was not as great in patients with infections as in normal subjects (13).

Goetsch, Moore and Minnich (16) have observed serum iron values from 0.622 to $3.86 \mathrm{mg}$. per cent in patients following the intravenous injection of massive doses of iron (from 0.608 to $1.32 \mathrm{gm}$. as colloidal hydroxide and colloidal ferric oxide). Moore, Arrowsmith, Welch, and Minnich (17) observed serum iron values in dogs as high as $1.60 \mathrm{mg}$. per cent after the intravenous administration of $1 \mathrm{mg}$. $\mathrm{Fe}^{++}$per kilogram of body weight. These experiments differ from ours in that much larger doses were used. It may be that with the administration of doses such as Moore and his associates gave, the iron combines with other proteins.

As far as our own observations are concerned, the failure of the serum iron to rise above the level of the TIBC when $0.137 \mathrm{mg}$. $\mathrm{Fe}^{++}$per kilogram were given intravenously, appeared to be so consistent that we would suggest that the most accu- 
rate method of determining the TIBC is by measuring the serum iron five minutes after the injection of a supersaturating amount of iron.

It may be noted in passing that, since the toxicity of injected iron seems to be dependent upon the presence of unbound iron in the serum, it is unlikely that any one particular iron compound, other than iron in combination with protein or colloidal iron, can be less toxic than another.

\section{SUM MARY}

1. The total iron-binding capacity (TIBC) of the serum was measured in 30 normal individuals. The mean \pm S.D. was $359 \pm 30.8 \mu \mathrm{g}$ per cent. The saturation of the iron-binding protein with iron was found to be $35 \pm 6.4$ per cent.

2. The total iron-binding capacity of the serum was measured in 13 patients with chronic infection, in two dogs in which sterile abscesses were produced, and in a single dog given an acute in- fection. The TIBC was found to be significantly reduced in each instance. The reduction in the serum iron was proportionately greater than the reduction in iron-binding capacity with the result that the per cent saturation was lowered.

3. The total iron-binding capacity of the serum was also measured in six patients with iron deficiency and found to be increased. The per cent saturation of the iron-binding component was less than 10 in each instance.

4. The administration of metal-combining globulin (Fraction IV-7) to two patients with chronic infections resulted in a temporary increase to normal in the total iron-binding capacity of the serum. Following the administration of this fraction the intravenous injection of iron resulted in a greater initial five-minute rise in the serum iron than previously but the rate of disappearance of the iron from the serum was not significantly affected. Furthermore, the temporary increase in

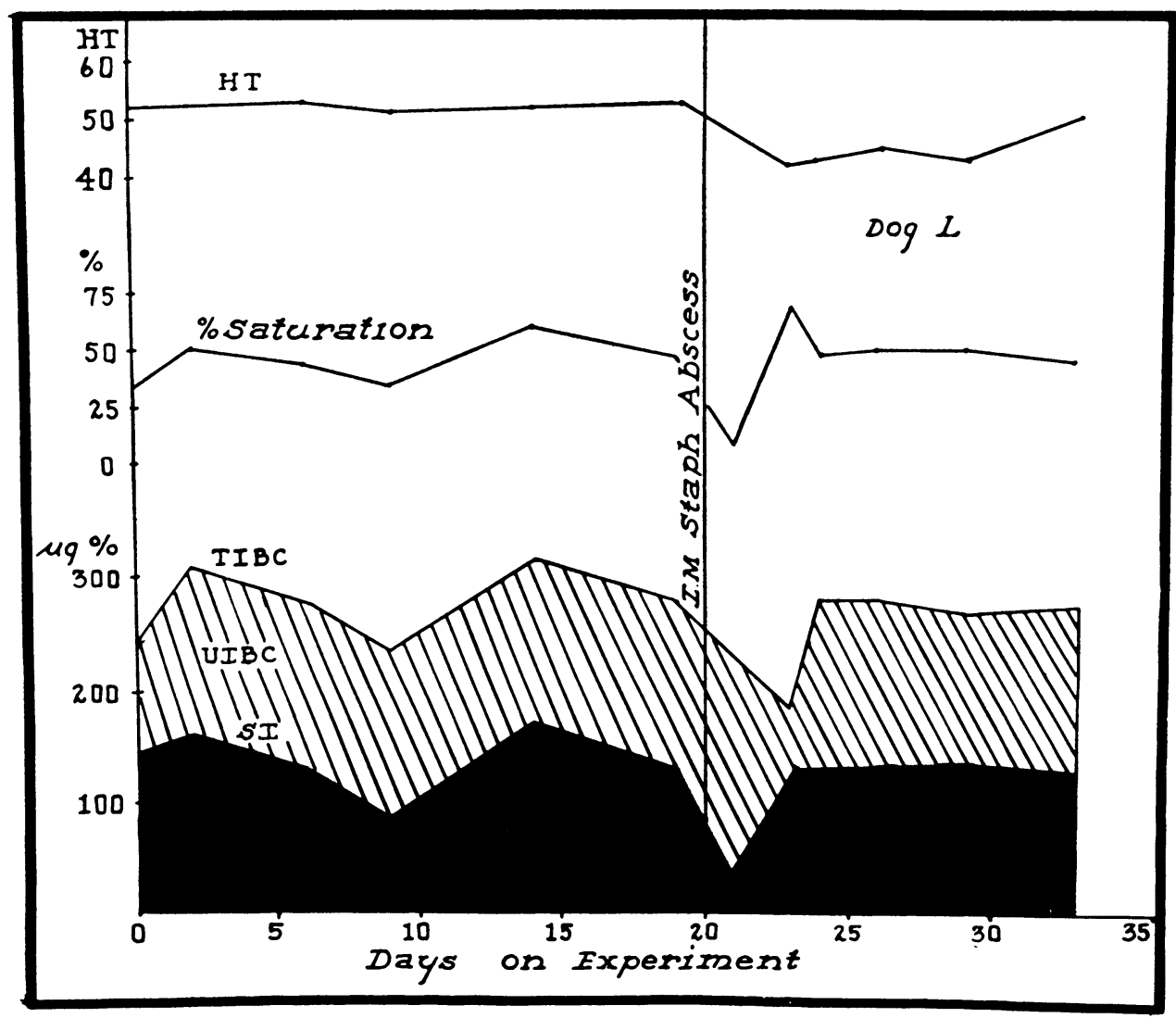

Fig. 14. Showing the Effect of the Intramuscular Injection of Staphylococci on the Total Iron-Binding Capacity and the Serum Iron in a Dog

For symbols see Figure 5. 




Fig. 15. The Effect of the Repeated Intramuscular Injection of Turpentine on the Total Iron-Binding Capacity and the Serum Iron of a Dog

For symbols see Figure 5.

the iron-binding capacity of the serum did not result in a detectable mobilization of iron into the blood.

5. The administration of typhoid vaccine to a patient produced a transient hypoferremia without a significant change in the iron-binding capacity of the serum.

6. These observations would indicate that the hypoferremia which accompanies infections is not the result of a reduction in the iron-binding capacity of the serum but is dependent upon some other factor.

7. The observations of Holmberg and of Laurell that the "braking" mechanism described by Waldenström is attributable to the fact that iron, in excess of that which can be bound, rapidly leaves the blood stream, and their conclusion that the intravenous administration of iron in excess of the amount which can be bound produces toxic symptoms, have been confirmed.

\section{ACKNOWLEDGMENT}

For the supply of Fraction IV-7 as well as crystallized metal-combining globulin, we are indebted to Dr. Edwin J. Cohn, Harvard Medical School, Boston, Massachusetts.

\section{BIBLIOGRAPHY}

1. Barkan, G., Eisenstudien; die Verteilung des leicht abspaltbaren Eisens zwischen Blutkörperchen und Plasma und sein Verhalten unter experimentellen Bedingungen. Ztschr. f. physiol. Chem., 1927, 171, 194.

2. Barkan, G., Uber Bestimmungsmethodik und Eigenschaften des "leicht abspaltbaren" Bluteisens. Ztschr. f. physiol. Chem., 1933, 216, 1.

3. Tompsett, S. L., The iron of the plasma. Biochem. J., 1940, 34, 959.

4. Vahlquist, B., Das Serumeisen, Diss. Uppsala, Appelbergs Boktrycheriaktiebolag, 1941.

5. Barkan, G., and Schales, O., Chemischer Aufbau und physiologische Bedeutung des "leicht abspaltbaren" Bluteisens. Ztschr. f. physiol. Chem., 1937, 248, 96.

6. Schade, A. L., and Caroline, L., Raw hen egg white 


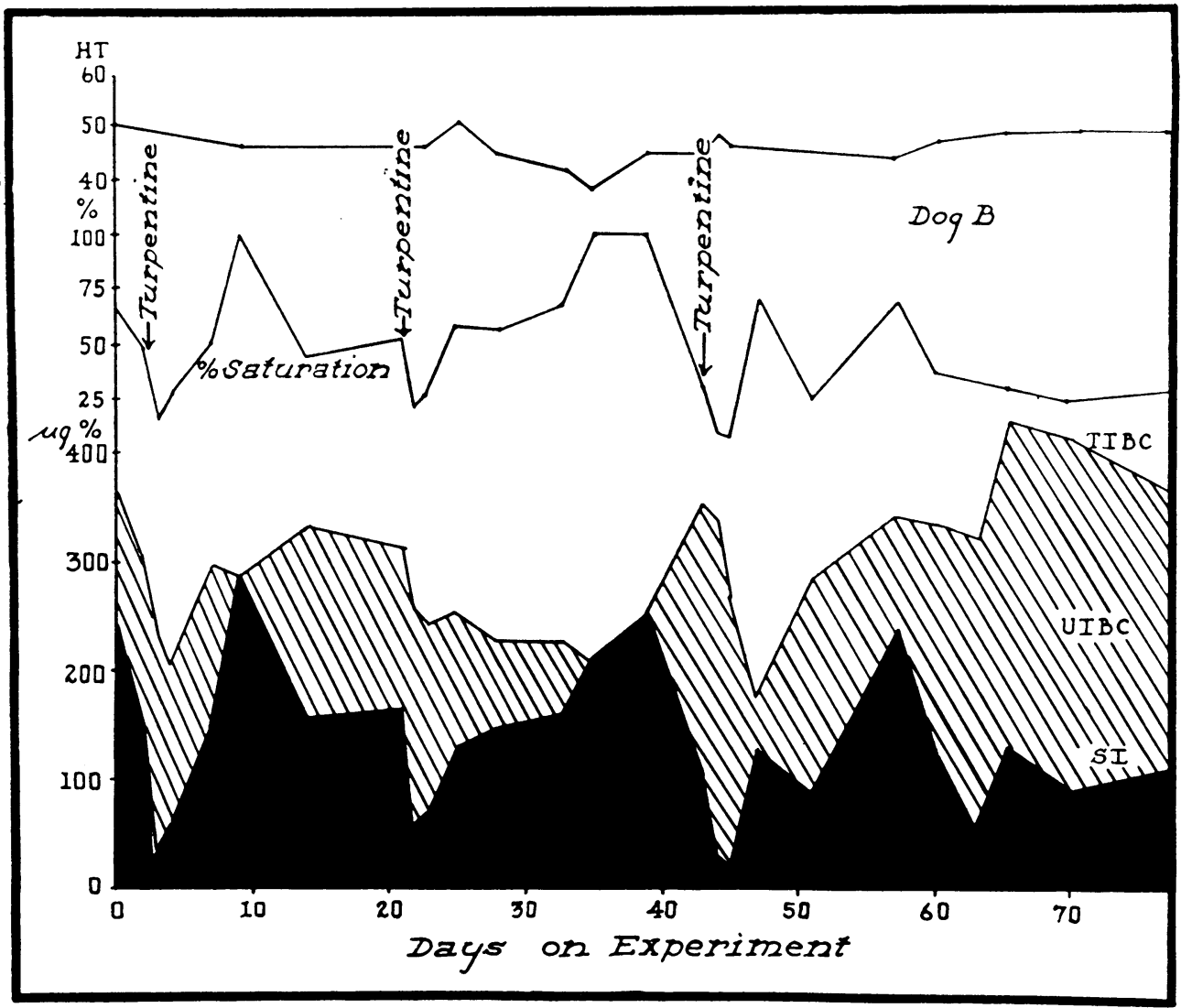

Fig. 16. The Effect of the Repeated Intramuscular Injection of Turpentine on the Total Iron-Binding Capacity and the Serum Iron of a Dog

For symbols see Figure 5.

and the role of iron in growth inhibition of Shigella dysenteriae, Staphylococcus aureus, Escherichia coli and Saccharomyces cerevisiae. Science, 1944, 100, 14.

7. Schade, A. L., and Caroline, L., An iron-binding component in human blood plasma. Science, 1946, $104,340$.

8. Edsall, J. T., The Plasma Proteins and Their Fractionation. Advances in Protein Chemistry, 3, 383, 1947, Academic Press, New York.

9. Skouge, F., Klinische und experimentelle Untersuchungen über das Serumeisen, Oslo, 1939.

10. Waldenström, J., Järnbelastningar Och Vad De Lära Oss Om Jarnomsättningen. Ferrosan, Malmo, 1944.

11. Holmberg, C. G., and Laurell, C. B., Studies on the capacity of serum to bind iron. A contribution to our knowledge of the regulation mechanism of serum iron. Acta Physiol. Scand., 1945, 10, 307.

12. Laurell, C. B., Studies on the transportation and metabolism of iron in the body with special reference to the iron-binding component in human plasma. Acta Physiol. Scand., 1947, Vol. 14, Supplementum 46.
13. Cartwright, G. E., Lauritsen, M. A., Jones, P. J., Merrill, I. M., and Wintrobe, M. M., The anemia of infection. I. Hypoferremia, hypercupremia, and alterations in porphyrin metabolism in patients. J. Clin. Invest., 1946, 25, 65.

14. Greenberg, G. R., Ashenbrucker, H., Lauritsen, M., and Wintrobe, M. M., The anemia of infection. IV. The lack of relationship between the diversion of iron from the plasma and the origin of the anemia. J. Clin. Invest., 1947, 26, 114.

15. Barkan, G., and Walker, B. S., Determination of serum iron and pseudohemoglobin iron with Ophenanthroline. J. Biol. Chem., 1940, 135, 37.

16. Goetsch, A. T., Moore, C. V., and Minnich, V., Observations on the effect of massive doses of iron given intravenously to patients with hypochromic anemia. Blood, 1946, 1, 129.

17. Moore, C. V., Arrowsmith, W. R., Welch, J., and Minnich, V., Studies in iron transportation and metabolism. IV. Observations on the absorption of iron from the gastro-intestinal tract. J. Clin. Invest., 1939, 18, 553. 